\title{
Children and adolescents adjustment to parental multiple sclerosis: a systematic review
}

\author{
Neda Razaz ${ }^{1 *}$, Reza Nourian ${ }^{1}$, Ruth Ann Marrie ${ }^{2}$, W Thomas Boyce ${ }^{3}$ and Helen Tremlett ${ }^{4,5}$
}

\begin{abstract}
Background: Families are the primary source of support and care for most children. In Western societies, 4 to 12\% of children live in households where a parent has a chronic illness. Exposure to early-life stressors, including parenting stress, parental depression and parental chronic disease could lead to harmful changes in children's social, emotional or behavioural functioning. Little is known about the child living with a parent who has Multiple Sclerosis (MS). We systematically reviewed the literature regarding possible effects of having a parent with MS on the child's or adolescent's psychosocial adjustment.

Methods: The following databases: MEDLINE, PsychInfo, CINAHL, EMBASE, Web of Knowledge, ERIC, and ProQuest Digital Dissertations were searched (from 1806 to December 2012). References from relevant articles were also manually searched. Selected studies were evaluated using the Graphic Appraisal Tool for Epidemiology (GATE).

Results: The search yielded 3133 titles; 70 articles were selected for full text review. Eighteen studies met inclusion criteria. Fourteen studies employed quantitative techniques, of which 13 were cross-sectional and one was longitudinal. Four studies were both qualitative and cross-sectional in design. Only 2 of 18 studies were rated as having high methodological quality. Overall, eight studies reported that children of MS patients exhibited negative psychosocial traits compared with children of "healthy" parents. Specifically for adolescents, greater family responsibilities were linked to lower social relationships and higher distress. Three studies indicated that parental MS was associated with positive adjustment in children and adolescents, such as higher personal competence, while four found no statistically significant differences.

Conclusion: Although having a parent with MS was often reported to have negative psychosocial effects on children and adolescents, there was a lack of consensus and some positive aspects were also found. However, few high quality studies were identified which makes it difficult to draw evidence-based conclusions at this point. There are potentially important, long-term impacts of early life stressors, such as having a parent with a chronic disease, on subsequent life chances and health, and thus more extensive and higher quality research in this area is greatly needed.
\end{abstract}

Keywords: Multiple sclerosis, Child development, Parenting, Child of impaired parents, Cohort studies

\section{Background}

In Western societies, 4 to $12 \%$ of children and adolescents aged 18 and under live in households where a parent has a chronic illness [1-3]. Increasing evidence suggests that having a parent with a chronic condition can put children at a higher risk of developing emotional and behavioural difficulties due to changes in parent-child interactions [3].

\footnotetext{
* Correspondence: neda.razaz@gmail.com

'School of Population and Public Health, Faculty of Medicine, University of British Columbia, 2206 East Mall, Vancouver, British Columbia, V6T 1Z3, Canada

Full list of author information is available at the end of the article
}

Multiple sclerosis (MS) is a chronic degenerative disease of the central nervous system and is the most common non-traumatic cause of neurological disability among young adults in the Western world [4]. MS typically manifests between the ages of 20 and 40 years, at a life stage when parenting is an important issue for many [5]. Interestingly, reproductive decision-making by people with MS seems to follow the same pattern as the general population [6]. Consequently, many children are exposed to a parent trying to cope with a potentially disabling chronic condition. MS is a particularly challenging disease, and the unpredictable and variable clinical course can cause considerable stress and anxiety on patients and their families $[7,8]$.

\section{Biomed Central}

(c) 2014 Razaz et al.; licensee BioMed Central Ltd. This is an Open Access article distributed under the terms of the Creative Commons Attribution License (http://creativecommons.org/licenses/by/4.0), which permits unrestricted use, distribution, and reproduction in any medium, provided the original work is properly credited. The Creative Commons Public Domain Dedication waiver (http://creativecommons.org/publicdomain/zero/1.0/) applies to the data made available in this article, unless otherwise stated. 
While much research and resources now focus on the child or adolescent who has MS, less is known about the child living with a parent who has MS $[9,10]$. We aimed to systematically review the literature to address the question - what are the possible effects on children and adolescents' psychosocial adjustment of having a parent with $M S$ ? In doing so, we aimed to illuminate the impact of parental health issues on children's development, and open avenues for early identification and potential preventive interventions.

\section{Methods}

\section{Search strategy}

A comprehensive search of the literature was undertaken in December 2012, accessing the following databases: MEDLINE, PsychInfo (from 1806), CINAHL (from 1982), EMBASE (from 1974), Web of Knowledge (from 1900), ERIC (from 1966), and ProQuest Digital Dissertations (from 1980). Search terms included 'Multiple Sclerosis', 'family', 'Parents', 'Parent-child Relations', 'Child of Impaired Parents', 'Nuclear Family' and 'Caregivers' (see Additional file 1 online for detailed strategy). References from identified articles were also hand searched for potentially relevant articles. Although we searched selected conference proceedings for emerging research, specifically the 2010, 2011 and 2012 proceedings from the annual meetings of the American Academy of Neurology and the European and American Committees of Treatment and Research in Multiple Sclerosis (the largest conferences covering MS research), we did not find any relevant abstracts to include in our data synthesis.

\section{Inclusion and exclusion criteria}

Only original full-text peer-reviewed published studies fulfilling the following criteria were included (1) school-aged children or adolescents, under the age of 18 years, were part of the study sample; (2) at least one parent was diagnosed with MS; (3) evaluated potential factors associated with parental MS and psychosocial adjustment in children and adolescents was included, regardless of the actual direction of findings (positive, negative or neutral); (4) findings were reported using statistical or qualitative analysis; and (5) were published in English. Non-empirical studies were excluded (i.e. clinical reports, reviews, comments, experiences, case studies, or opinions).

\section{Data collection process}

Two individuals independently screened the titles and abstracts of all identified studies (N.R. \& R.N.). All studies considered eligible underwent a full-text review by one reviewer (N.R.). Data extraction was conducted using a pre-piloted form, which captured: study design, sample size, duration of exposure (to MS), outcomes measured, main findings and methodological quality (see Table 1).
Accuracy of data abstraction was cross-checked and confirmed, on a random sample of 10 studies out of the 70 studies that underwent full-text review, by a second reviewer (R.N.). The level of agreement between the two reviewers was $90 \%$ and any disagreements were resolved through consensus.

\section{Quality appraisal for included studies}

No standard exists for conducting quality appraisals for observational studies in the context of a systematic review, so we adapted the Graphic Appraisal Tool for Epidemiology (GATE) [11], and supplemented this tool with topicspecific criteria (see Additional file 2 online), to assess both qualitative and quantitative studies. Each study received a summary quality score of low, medium, or high. It should be noted that a low quality score does not negate the contribution of a given study, especially in an emerging field where methods may not be well developed, but reflects methodological rigor in the context of all observational studies.

Due to heterogeneity in outcomes and methodologies in the selected studies, a meta-analysis was not possible; therefore a narrative analysis of data was conducted, with studies broadly grouped into those finding a negative, positive or no measureable effect on the developing child living with a parent who has MS, as well as by study design (e.g. quantitative vs qualitative and use of a comparison group).

\section{Results}

\section{Literature search}

The initial search returned 3133 citations, with 1114 remaining after duplicates were removed. Of these, 1044 articles were excluded at the title/abstract screening level for not fulfilling study criteria. Seventy articles underwent full-text review of which 52 were excluded for the following reasons: 1 included a population entirely outside the specified age range, 12 had a non-empirical study design, 7 included parents with a range of chronic conditions, without separating out MS, 8 were dissertation abstracts and 24 articles did not focus on psychosocial outcomes. Eighteen studies met the inclusion criteria (Figure 1) and were published between 1959 and 2012.

\section{Description of included studies}

Of the 18 eligible studies (see Table 1), locations of study participants were as follows: United States $(n=4)$ $[12,15,16,18]$, Canada $(n=3)[13,17,22]$, Switzerland $(n=2$, 1 of which also included Germany and Greece) [8,23], Greece $(n=2) \quad[7,21]$, UK $(n=1)$ [14], Israel $(n=2)$ $[24,25]$, Australia $(n=4)[5,10,19,20]$. Cohort sizes ranged from 8 [10] to 281 [12], with a total of 2051 children or adolescents studied overall. There were a higher number of mothers with MS than fathers, which could be partly 
Table 1 Summary of studies examining exposure to parental MS and psychosocial adjustment in children and adolescents

\begin{tabular}{|c|c|c|c|c|c|c|c|c|}
\hline Author/Year & Country & Study design & $\begin{array}{l}\text { Sample (age } \\
\text { range of children) }\end{array}$ & $\begin{array}{l}\text { A. Exposure } \\
\text { to parental } \\
\text { MS } \\
\text { B. Parental } \\
\text { MS duration }\end{array}$ & Outcomes measured & Evaluator & Main findings & ${ }^{*}$ Quality [11] \\
\hline \multirow[t]{8}{*}{$\begin{array}{l}\text { Arnaud } \\
1959 \text { [12] }\end{array}$} & \multirow[t]{8}{*}{$\begin{array}{l}\text { United } \\
\text { States }\end{array}$} & \multirow[t]{8}{*}{$\begin{array}{l}\text { Quantitative/ } \\
\text { Cross-sectional }\end{array}$} & \multirow{8}{*}{$\begin{array}{l}60 \text { children with an MS } \\
\text { parent and } 221 \text { with a } \\
\text { "healthy" parent(s) } \\
\text { (7-16 years) }\end{array}$} & \multirow{8}{*}{$\begin{array}{l}\text { A. Mean = } \\
7.2 \text { years } \\
\text { (SD: } 2.5) \text { B. } \\
\text { Range: } 3-17 \\
\text { years }\end{array}$} & $\begin{array}{l}\text { aPsychological } \\
\text { characteristics: }\end{array}$ & \multirow[t]{8}{*}{ Third Party: Author } & \multirow{8}{*}{$\begin{array}{l}\text { Children with a parent } \\
\text { with MS scored higher } \\
\text { in: Body concerns } \\
\text { Dysphoric feelings, } \\
\text { Hostility, Constraint in } \\
\text { interpersonal relations, } \\
\text { Dependency needs }\end{array}$} & \multirow[t]{8}{*}{ Medium } \\
\hline & & & & & (1) General anxiety & & & \\
\hline & & & & & (2) Body concern & & & \\
\hline & & & & & (3) Dysphoria & & & \\
\hline & & & & & (4) Hostility & & & \\
\hline & & & & & $\begin{array}{l}\text { (5) Constraint in } \\
\text { interpersonal relations }\end{array}$ & & & \\
\hline & & & & & $\begin{array}{l}\text { (6) Dependency } \\
\text { longings }\end{array}$ & & & \\
\hline & & & & & (7) False maturity & & & \\
\hline $\begin{array}{l}\text { Blackford } \\
1999[13]\end{array}$ & Canada & $\begin{array}{l}\text { Qualitative/ } \\
\text { Cross-sectional }\end{array}$ & $\begin{array}{l}22 \text { children with an MS } \\
\text { parent. No comparison } \\
\text { group. }\end{array}$ & $\begin{array}{l}\text { Did not } \\
\text { specify }\end{array}$ & $\begin{array}{l}\text { Children's descriptions } \\
\text { of life with a parent } \\
\text { who has MS }\end{array}$ & Third Party: Author & $\begin{array}{l}\text { Children with an MS } \\
\text { parent described higher } \\
\text { personal competence, } \\
\text { hopefulness, and } \\
\text { spirituality. Negative } \\
\text { factors that children } \\
\text { encountered were } \\
\text { attributable more to } \\
\text { society than to their } \\
\text { parent's condition. }\end{array}$ & Low \\
\hline \multirow[t]{5}{*}{$\begin{array}{l}\text { Bogosian } \\
2011[14]\end{array}$} & \multirow[t]{5}{*}{ UK } & \multirow[t]{5}{*}{$\begin{array}{c}\text { Qualitative/ } \\
\text { Cross-sectional }\end{array}$} & \multirow{5}{*}{$\begin{array}{l}15 \text { children with an MS } \\
\text { parent ( } 13-18 \text { years). No } \\
\text { comparison group. }\end{array}$} & \multirow[t]{5}{*}{$\begin{array}{l}\text { Did not } \\
\text { specify }\end{array}$} & $\begin{array}{l}\text { Interviews were } \\
\text { conduced asking }\end{array}$ & \multirow[t]{5}{*}{ Third Party: Trained Interviewer } & \multirow{5}{*}{$\begin{array}{l}\text { Adolescents described } \\
\text { both positive and } \\
\text { negative experiences } \\
\text { related to having a } \\
\text { parent with MS. Benefits } \\
\text { to having a parent with } \\
\text { MS included reports of } \\
\text { feeling more empathetic } \\
\text { to others and more } \\
\text { grown-up. Negative } \\
\text { impacts included family } \\
\text { tension, less time to } \\
\text { spend with friends, and } \\
\text { worries about the future. }\end{array}$} & \multirow[t]{5}{*}{ High } \\
\hline & & & & & $\begin{array}{l}\text { - What is it like for you } \\
\text { to have a parent with } \\
\text { MS }\end{array}$ & & & \\
\hline & & & & & $\begin{array}{l}\text { - How does your } \\
\text { mum's/dad's MS } \\
\text { affect your? }\end{array}$ & & & \\
\hline & & & & & a. Social life & & & \\
\hline & & & & & b. Family life & & & \\
\hline $\begin{array}{l}\text { Brandt } \\
1998 \text { [15] }\end{array}$ & $\begin{array}{l}\text { Unites } \\
\text { States }\end{array}$ & $\begin{array}{l}\text { Quantitative/ } \\
\text { Cross-sectional }\end{array}$ & $\begin{array}{l}174 \text { children with an MS } \\
\text { parent ( } 7-17 \text { years). } \\
\text { Population 'norms' as } \\
\text { comparison group. }\end{array}$ & $\begin{array}{l}\text { Did not } \\
\text { specify }\end{array}$ & 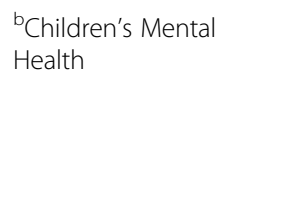 & Parent without MS & $\begin{array}{l}25 \% \text { of children in this } \\
\text { study ( } 45 \text { of the } 174 \text { ) } \\
\text { were classified as being } \\
\text { "at risk" for a mental } \\
\text { health problem } \\
\text { compared with the rate }\end{array}$ & Low \\
\hline
\end{tabular}




\section{Table 1 Summary of studies examining exposure to parental MS and psychosocial adjustment in children and adolescents (Continued)}

\begin{tabular}{|c|c|c|c|c|c|c|c|c|}
\hline & & & & & & & $\begin{array}{l}\text { of the prevalence rate in } \\
\text { the general child } \\
\text { population of } 12 \% \text { to } \\
20 \% \text {. }\end{array}$ & \\
\hline \multirow[t]{2}{*}{$\begin{array}{l}\text { Crist } \\
1993 \text { [16] }\end{array}$} & \multirow[t]{2}{*}{$\begin{array}{l}\text { United } \\
\text { States }\end{array}$} & \multirow[t]{2}{*}{$\begin{array}{l}\text { Quantitative/ } \\
\text { Cross-sectional }\end{array}$} & \multirow{2}{*}{$\begin{array}{l}31 \text { girls with mothers with MS } \\
\text { and } 34 \text { girls with } \\
\text { "healthy" mother(s) (8-12 years) }\end{array}$} & $\begin{array}{l}\text { A. Minimum = } \\
2 \text { years }\end{array}$ & \multirow{2}{*}{$\begin{array}{l}\text { Mother-daughter } \\
\text { interactions during a } \\
\text { work task and a play } \\
\text { task assessed as: } \\
\text { receptiveness, } \\
\text { directiveness, and } \\
\text { dissuasiveness }\end{array}$} & \multirow[t]{2}{*}{ Third party: Author } & \multirow{2}{*}{$\begin{array}{l}\text { Similar proportions of } \\
\text { receptive, directive, and } \\
\text { dissuasive behaviors } \\
\text { were used by mothers } \\
\text { with MS and their } \\
\text { daughters compared } \\
\text { with those used by } \\
\text { control group mothers } \\
\text { and their daughters. }\end{array}$} & \multirow[t]{2}{*}{ Medium } \\
\hline & & & & $\begin{array}{l}\text { B. Range: } \\
2 \text { - } 28 \text { years }\end{array}$ & & & & \\
\hline $\begin{array}{l}\text { De Judicibus } \\
2004[5]\end{array}$ & Australia & $\begin{array}{l}\text { Quantitative/ } \\
\text { Cross-sectional }\end{array}$ & $\begin{array}{l}48 \text { children with an MS } \\
\text { parent ( } 4-16 \text { years). No } \\
\text { comparison group. }\end{array}$ & $\begin{array}{l}\text { B. Mean = } \\
5.6 \text { years } \\
\text { (ranged: } \\
\text { 1- } 19 \text { years) }\end{array}$ & $\begin{array}{l}\text { 'Children's emotional } \\
\text { and behavioural well- } \\
\text { being }\end{array}$ & Parent with MS & $\begin{array}{l}\text { Children with an MS } \\
\text { parent demonstrated } \\
\text { more difficulties in how } \\
\text { they related to others, } \\
\text { the distress they } \\
\text { experienced and how } \\
\text { they managed their } \\
\text { lives. However, they did } \\
\text { not reveal higher levels } \\
\text { of clinical symptoms } \\
\text { requiring treatment. }\end{array}$ & Low \\
\hline $\begin{array}{l}\text { Diareme } \\
2006[7]\end{array}$ & Greece & $\begin{array}{l}\text { Quantitative/ } \\
\text { Cross-sectional }\end{array}$ & $\begin{array}{l}56 \text { children with an MS } \\
\text { parent and } 64 \text { with a } \\
\text { "healthy" parent(s) (4-17 years) }\end{array}$ & $\begin{array}{l}\text { B. Mean }= \\
10.3 \text { years } \\
\text { (SD: } 9.5)\end{array}$ & $\begin{array}{l}\text { d, e'Children's emotional } \\
\text { and behavioural } \\
\text { problems }\end{array}$ & Child & $\begin{array}{l}\text { Children whose parents, } \\
\text { especially mothers, had } \\
\text { MS presented greater } \\
\text { emotional and } \\
\text { behavioural problems } \\
\text { than comparison } \\
\text { children. Children's } \\
\text { problems were } \\
\text { positively associated } \\
\text { with maternal } \\
\text { depression and family } \\
\text { dysfunction. Family } \\
\text { dysfunction predicted } \\
\text { children's overall and } \\
\text { externalizing problems, } \\
\text { while the severity of } \\
\text { impairment of the MS } \\
\text { mother predicted } \\
\text { children's internalizing } \\
\text { problems. }\end{array}$ & Medium \\
\hline $\begin{array}{l}\text { Kikuchi } \\
1987 \text { [17] }\end{array}$ & Canada & $\begin{array}{l}\text { Qualitative/ } \\
\text { Cross-sectional }\end{array}$ & $\begin{array}{l}32 \text { children with an MS } \\
\text { parent ( } 6 \text { - } 17 \text { years). No } \\
\text { comparison group. }\end{array}$ & $\begin{array}{l}\text { Did not } \\
\text { specify } \\
\text { (although at } \\
\text { the time of } \\
\text { MS diagnosis }\end{array}$ & $\begin{array}{l}\text { Children reported } \\
\text { quality of life }\end{array}$ & Third Party: Trained Interviewer & $\begin{array}{l}\text { For most part children } \\
\text { reported a good quality } \\
\text { of life. Although, } \\
\text { children expressed } \\
\text { limited knowledge of }\end{array}$ & Medium \\
\hline
\end{tabular}


Table 1 Summary of studies examining exposure to parental MS and psychosocial adjustment in children and adolescents (Continued)

\begin{tabular}{|c|c|c|c|c|c|c|c|c|}
\hline & & & & $\begin{array}{l}\text { subjects } \\
\text { ranged from } \\
\text { newborns to } \\
15 \text { years; } \\
\text { mean }= \\
6.5 \text { years) }\end{array}$ & & & $\begin{array}{l}\text { MS and feelings of fear, } \\
\text { anger and sadness. }\end{array}$ & \\
\hline \multirow[t]{2}{*}{$\begin{array}{l}\text { Olga } \\
1974[18]\end{array}$} & $\begin{array}{l}\text { United } \\
\text { States }\end{array}$ & $\begin{array}{l}\text { Quantitative/ } \\
\text { Cross-sectional }\end{array}$ & $\begin{array}{l}124 \text { children with an MS parent } \\
\text { and } 60 \text { with a "healthy" parent(s) } \\
\text { (7-11 years) }\end{array}$ & $\begin{array}{l}\text { A. Minimum = } \\
2 \text { years }\end{array}$ & fBody image & Child & $\begin{array}{l}\text { Body image scores did } \\
\text { not differ between } \\
\text { groups }\end{array}$ & Low \\
\hline & & & & & & & $\begin{array}{l}\text { Body image distortion } \\
\text { tended to be greater in } \\
\text { girls with MS mothers } \\
\text { than girls with MS fathers } \\
\text { or boys with MS mother }\end{array}$ & \\
\hline $\begin{array}{l}\text { Pakenham } \\
2006 \text { [19] }\end{array}$ & Australia & $\begin{array}{l}\text { Quantitative/ } \\
\text { Cross-sectional }\end{array}$ & $\begin{array}{l}48 \text { children with an MS parent } \\
\text { and } 145 \text { with a "healthy" } \\
\text { parent(s) (10-25 years) }\end{array}$ & $\begin{array}{l}\text { B. Mean }= \\
9 \text { years } \\
\text { (SD: } 7 \text {; range: } \\
4 \text { months to } \\
29 \text { years) }\end{array}$ & $\begin{array}{l}\text { Children's positive } \\
\text { (benefit finding, life } \\
\text { satisfaction and positive } \\
\text { affect) and negative } \\
\text { (distress and health } \\
\text { status) adjustment }\end{array}$ & Child & $\begin{array}{l}\text { Children with a parent } \\
\text { with MS had poorer } \\
\text { adjustment, greater } \\
\text { family caregiving } \\
\text { responsibilities and } \\
\text { lower levels of life } \\
\text { satisfaction and positive } \\
\text { affect }\end{array}$ & Low \\
\hline $\begin{array}{l}\text { Pakenham } \\
2012[20]\end{array}$ & Australia & $\begin{array}{l}\text { Quantitative/ } \\
\text { Longitudinal }\end{array}$ & $\begin{array}{l}\text { Time 1: } 130 \text { children with an MS } \\
\text { parent ( } 10-20 \text { years) Time } 2 \\
\text { (After } 12 \text { months): } 91 \text { children } \\
\text { with an MS parent ( } 10-20 \text { years). } \\
\text { No comparison group. }\end{array}$ & $\begin{array}{l}\text { At time } 1: B . \\
\text { Mean }= \\
8.2 \text { years (SD: } \\
5.8 \text {; range: } \\
4 \text { months to } \\
25 \text { years) }\end{array}$ & $\begin{array}{l}{ }^{9} \text { Children's negative } \\
\text { (behavioural emotional } \\
\text { difficulties, somatisation) } \\
\text { and positive (life } \\
\text { satisfaction, positive } \\
\text { affect, prosocial } \\
\text { behaviour) adjustment }\end{array}$ & $\begin{array}{l}\text { - Child - Parent with MS - Parent } \\
\text { without MS }\end{array}$ & $\begin{array}{l}\text { At time } 1 \text { higher total } \\
\text { caregiving was } \\
\text { associated with lower } \\
\text { life satisfaction and } \\
\text { higher somatization and } \\
\text { total difficulties. Higher } \\
\text { total difficulties were } \\
\text { also associated with } \\
\text { greater social-emotional } \\
\text { care. At time 2, higher } \\
\text { caregiving responsibility } \\
\text { was associated with } \\
\text { lower life satisfaction } \\
\text { and higher total } \\
\text { caregiving was associated } \\
\text { with increased prosocial } \\
\text { behaviour. Further, time } 1 \\
\text { instrumental and social- } \\
\text { emotional care domains } \\
\text { were associated with } \\
\text { poorer time } 2 \text { adjustment. }\end{array}$ & Low \\
\hline $\begin{array}{l}\text { Paliokosta } \\
2009[21]\end{array}$ & Greece & $\begin{array}{l}\text { Quantitative/ } \\
\text { Cross-sectional }\end{array}$ & $\begin{array}{l}56 \text { children with an MS } \\
\text { parent ( } 4-17 \text { years). No } \\
\text { comparison group. }\end{array}$ & $\begin{array}{l}\text { B. Mean }= \\
10.3 \text { years } \\
\text { (range }= \\
2 \text { months to } \\
21 \text { years) }\end{array}$ & 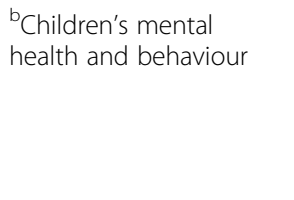 & $\begin{array}{l}\text { Third Party: Trained Interviewer - } \\
\text { Parent with MS - Parent without } \\
\text { MS - Child }\end{array}$ & $\begin{array}{l}\text { Children and } \\
\text { adolescents who had } \\
\text { "partial information" } \\
\text { about parental MS } \\
\text { presented with higher } \\
\text { scores in social }\end{array}$ & Low \\
\hline
\end{tabular}




\begin{tabular}{|c|c|c|c|c|c|c|c|c|}
\hline & & & & & & & $\begin{array}{l}\text { difficulties and } \\
\text { internalizing behaviours } \\
\text { as well as higher total } \\
\text { problems on the child } \\
\text { behaviour checklist. } \\
\text { They also presented } \\
\text { with higher score on } \\
\text { social problems. }\end{array}$ & \\
\hline & & & & & $\begin{array}{l}\text { - Interviews were also } \\
\text { conducted with the } \\
\text { child and the parent } \\
\text { about the amount of } \\
\text { information regarding } \\
\text { parental MS given to } \\
\text { child }\end{array}$ & & & \\
\hline $\begin{array}{l}\text { Peters } \\
1985 \text { [22] }\end{array}$ & Canada & $\begin{array}{l}\text { Quantitative/ } \\
\text { Cross-sectional }\end{array}$ & $\begin{array}{l}33 \text { children with a MS } \\
\text { parent and } 33 \text { with a } \\
\text { "healthy" parent(s) } \\
\text { (12-18 years) }\end{array}$ & $\begin{array}{l}\text { B. } \text { Mean = } \\
9.2 \text { years } \\
\text { (range: } 1.6 \text { - } \\
17.7 \text { years) }\end{array}$ & $\begin{array}{l}\text { hFamily cohesion, } \\
\text { expressiveness, conflict, } \\
\text { independence, } \\
\text { achievement } \\
\text { orientation, intellectual- } \\
\text { cultural orientation, } \\
\text { active-recreational, } \\
\text { moral-religious } \\
\text { emphasis, organizations } \\
\text { and control in a family }\end{array}$ & Child & $\begin{array}{l}\text { Children of MS parents } \\
\text { showed significant } \\
\text { differences in the } \\
\text { perception of their } \\
\text { family environment v.s } \\
\text { children of 'healthy' } \\
\text { parents. Lack of 'feeling } \\
\text { of togetherness' was } \\
\text { reported }\end{array}$ & Medium \\
\hline $\begin{array}{l}\text { Steck } \\
2005[23]\end{array}$ & Switzerland & $\begin{array}{l}\text { Quantitative/ } \\
\text { Cross-sectional }\end{array}$ & $\begin{array}{l}41 \text { children with an MS } \\
\text { parent }(6-18 \text { years). No } \\
\text { comparison group. }\end{array}$ & $\begin{array}{l}\text { A. Mean }= \\
3.5 \text { years (for } \\
\text { children }<12) \text {; } \\
\text { mean }= \\
8.2 \text { years (for } \\
\text { children }>12 \text { ) }\end{array}$ & $\begin{array}{l}\text { Children's indication for } \\
\text { psychotherapy }\end{array}$ & Third party: Trained Interviewer & $\begin{array}{l}\text { Half of the children } \\
\text { were estimated to } \\
\text { benefit from individual } \\
\text { psychotherapy aimed } \\
\text { at enhancing ability to } \\
\text { cope with the parental } \\
\text { MS. }\end{array}$ & Low \\
\hline $\begin{array}{l}\text { Steck } \\
2007[8]\end{array}$ & $\begin{array}{l}\text { Germany, } \\
\text { Greece, } \\
\text { Switzerland }\end{array}$ & $\begin{array}{l}\text { Quantitative/ } \\
\text { Cross-sectional }\end{array}$ & $\begin{array}{l}192 \text { children with an MS } \\
\text { parent (Mean = } 9.8 \text { years; } \\
\text { SD: } 4.8 \text { ). No comparison group. }\end{array}$ & $\begin{array}{l}\text { B. Mean }= \\
6.5 \text { years for } \\
\text { MS fathers; } \\
\text { Mean = } \\
7.7 \text { years for } \\
\text { MS mothers }\end{array}$ & $\begin{array}{l}{ }^{\mathrm{b}} \text { Children's mental } \\
\text { health and behaviour }\end{array}$ & $\begin{array}{l}\text { - Parent with MS Parent without } \\
\text { MS Child }\end{array}$ & $\begin{array}{l}\text { MS parents, especially } \\
\text { mothers, as well as } \\
\text { depressed mothers, or } \\
\text { depressed "healthy" } \\
\text { parents evaluated their } \\
\text { children's mental health } \\
\text { problems with a higher } \\
\text { prevalence within the } \\
\text { internalizing spectrum. If } \\
\text { two parents presented a } \\
\text { depressive state, the } \\
\text { prevalence of relevant } \\
\text { psychological } \\
\text { internalizing symptoms } \\
\text { was twice or three times } \\
\text { as high as the age } \\
\text { norms. }\end{array}$ & Low \\
\hline
\end{tabular}

mily environment $v$.s

of togetherness' was

parents, especially

mothers, as well as

parents evaluated their

prevalence within the

internalizing symptoms

as high as the age 
Table 1 Summary of studies examining exposure to parental MS and psychosocial adjustment in children and adolescents (Continued)

\begin{tabular}{|c|c|c|c|c|c|c|c|c|}
\hline $\begin{array}{l}\text { Turpin } \\
2008[10]\end{array}$ & Australia & $\begin{array}{l}\text { Qualitative/ } \\
\text { Cross-sectional }\end{array}$ & $\begin{array}{l}8 \text { children with an MS } \\
\text { parent ( } 7-14 \text { years). No } \\
\text { comparison group. }\end{array}$ & $\begin{array}{l}\text { Did not } \\
\text { specify }\end{array}$ & $\begin{array}{l}\text { Children's day-to-day } \\
\text { lives, their perceptions of } \\
\text { their parent's condition } \\
\text { and their thoughts about } \\
\text { the future }\end{array}$ & $\begin{array}{l}\text { Third Party: Occupational therapist } \\
\text { and a psychologist }\end{array}$ & $\begin{array}{l}\text { Children described } \\
\text { taking on additional } \\
\text { roles and responsibilities } \\
\text { that restricted their } \\
\text { participation in } \\
\text { developmentally } \\
\text { appropriate occupations. } \\
\text { Additional } \\
\text { responsibilities can } \\
\text { enhance children's skills } \\
\text { and provide pride and } \\
\text { stress. }\end{array}$ & High \\
\hline $\begin{array}{l}\text { Yahav } \\
2005[24]\end{array}$ & Israel & $\begin{array}{l}\text { Quantitative/ } \\
\text { Cross-sectional }\end{array}$ & $\begin{array}{l}56 \text { children with an MS } \\
\text { parent and } 156 \text { with a } \\
\text { "healthy" parent(s) } \\
\text { (10-18 years) }\end{array}$ & A. $>6$ months & $\begin{array}{l}\text { - A sense of personal } \\
\text { concern and } \\
\text { responsibility towards } \\
\text { parents } \\
\text { - Degree of } \\
\text { responsibility and } \\
\text { active protection of } \\
\text { parents } \\
\text { - Fear and anxiety } \\
\text { about parents' future } \\
\text { - Burden of tasks and } \\
\text { errands at home } \\
\text { - Anger }\end{array}$ & Third Party: Trained Interviewer & $\begin{array}{l}\text { Children of parents with } \\
\text { MS felt more } \\
\text { responsibility and } \\
\text { obligation than children } \\
\text { of healthy parents. They } \\
\text { also exhibited higher } \\
\text { degree of responsibility, } \\
\text { more fear and anxiety } \\
\text { related to MS, a greater } \\
\text { sense of burden and a } \\
\text { greater degree of anger. }\end{array}$ & Medium \\
\hline $\begin{array}{l}\text { Yahav } \\
2007 \text { [25] }\end{array}$ & Israel & $\begin{array}{l}\text { Quantitative/ } \\
\text { Cross-sectional }\end{array}$ & $\begin{array}{l}56 \text { children with an MS parent } \\
\text { and } 156 \text { with a "healthy" parent(s) } \\
\text { (10-18 years) }\end{array}$ & A. $>6$ months & $\begin{array}{l}{ }^{\text {e}} \text { Children's emotional } \\
\text { health and problem } \\
\text { areas: delinquent } \\
\text { behavior, aggression, } \\
\text { attention problems, } \\
\text { thought disorders, social } \\
\text { acceptance problems, } \\
\text { anxiety and depression, } \\
\text { somatic complaints, and } \\
\text { withdrawal behavior. }\end{array}$ & Third Party: Trained Interviewer & $\begin{array}{l}\text { Children with an MS } \\
\text { parent displayed higher } \\
\text { levels of depression and } \\
\text { anxiety than children } \\
\text { from the control group. } \\
\text { Furthermore, children in } \\
\text { the study group } \\
\text { reported a greater } \\
\text { degree of separation } \\
\text { anxiety, compared with } \\
\text { the control group. }\end{array}$ & Medium \\
\hline
\end{tabular}

*Graphic Appraisal Tool for Epidemiology (GATE).

Instruments used to measure the stated outcomes:

${ }^{\mathrm{a}}$ Rorschach test [26].

Child Behaviour Checklist [27].

Strengths and Difficulty Questionnaire [28].

Achenbach's Child Behaviour Checklist and Youth Self Report [29].

'Youth Self Report, [30] and Separation Individuation Test of Adolescence [31].

eDraw-A-Person [32], Semantic Differential [33] and The Body-Cathexis Scale [34].

9Youth Activities of Caregiving Scale [35].

${ }^{h}$ Family environment scale [36] 


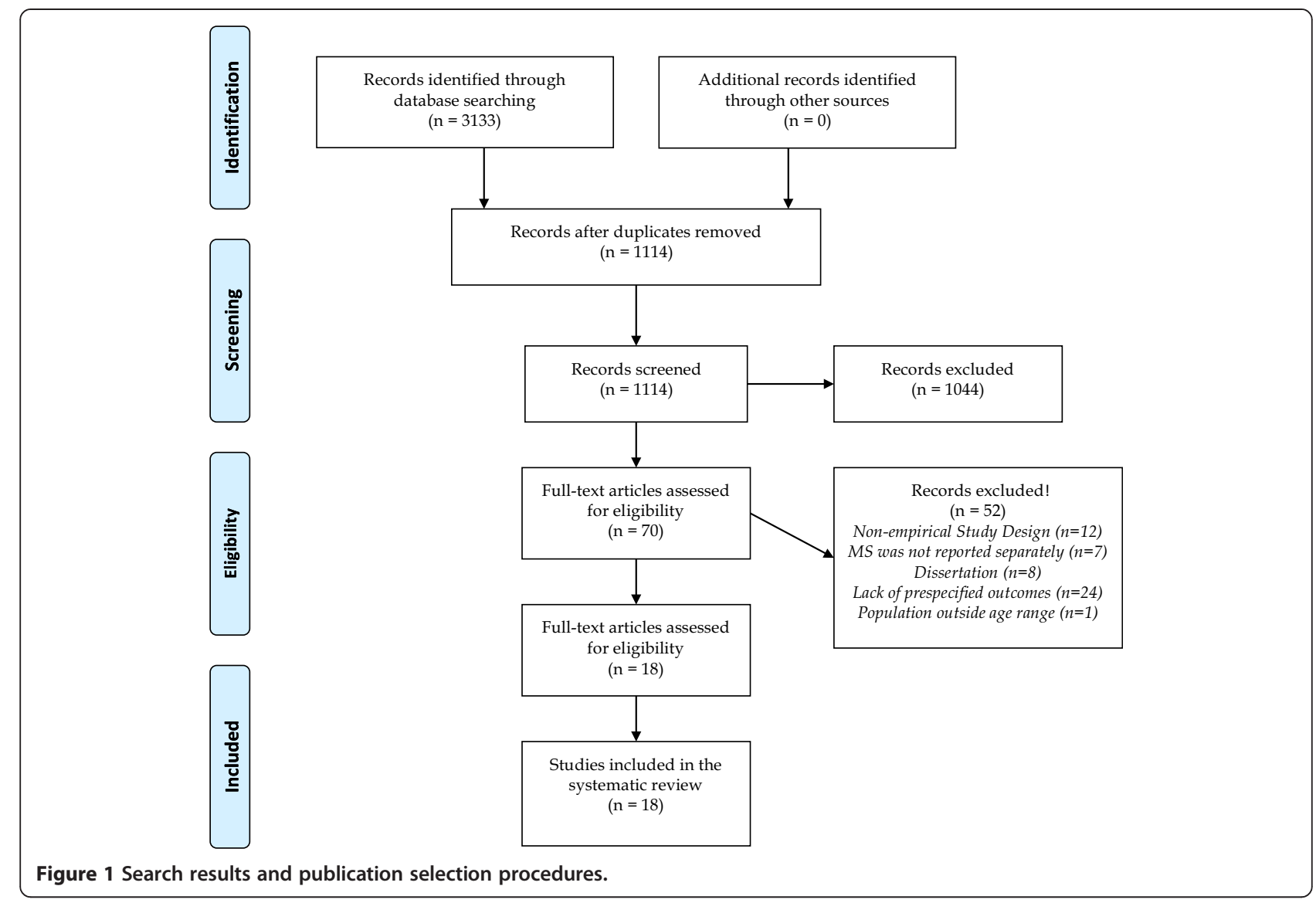

attributable to the higher prevalence of MS in females than males or to mothers being more interested in participating in studies related to children. Most participants were of Caucasian/European-American descent.

\section{Measurement of the exposure}

None of the 18 studies evaluated in this review specified the diagnostic criteria used for ascertaining MS cases. All study participants were recruited mainly through university neurology departments or specific national or local MS society centres. MS-specific clinical information on the affected parent were noted in some studies, with 2 providing a quantitative measure of disability (based on Kurtzke's Expanded Disability Status Scale [EDSS] [37] score), with the affected parents ranging from an EDSS of 2 to 7 , indicating 'slight weakness' through to 'restricted to a wheelchair' [16,23]. A further 9 studies provided other means of quantifying impairment, again with parents ranging from minimal impairment to wheelchair bound $[7,8,10,14,15,17,19-21]$. In the two studies reporting the affected parents' disease course, most had relapsingremitting MS $[5,14]$. Only six studies had enforced a minimum time of exposure to parental MS before enrollment $[7,16,18,21,24,25]$, the rest did not specify or only mentioned parents' disease duration.
Quality and methodological challenges of included studies Of the 18 studies included, 2 were considered of high quality, 7 moderate and 9 of low quality. Fourteen studies employed quantitative techniques, of which 13 were cross-sectional and one was longitudinal (and prospective) $[5,7,8,12,15,16,18-25]$. Four studies were both qualitative and cross-sectional in design $[10,13,14,17]$. Eight studies had a comparison group of children with 'healthy' parents $[7,12,16,18,19,22,24,25]$; the remainder had no control group.

\section{Outcome measures}

A broad range of outcomes were considered in the selected studies, including, anxiety, depression, peer relations, caregiving responsibility, family cohesion, body image, parent-child interaction and hopefulness. Some studies used validated, standardized questionnaires such as Child Behavioural Checklist or Youth Self Report [29] and others used study-specific questionnaires to measure the outcome. Outcomes were assessed either by an interviewer who administered the questionnaires or were selfreported by the parents, the children or both. Amongst studies that systematically evaluated this question, 8 found a negative association between exposure to parental MS and adjustment in their offspring. Five studies did not find 
an association and 5 studies found both positive and negative effects of caring for a parent with MS.

\section{Negative psychosocial aspects Quantitative studies with a comparison group}

Of the 8 studies with a suitable comparison group, 6 described negative psychosocial outcomes for children who had a parent with MS compared with the children of "healthy parents". Of these, two found higher levels of depression and anxiety [24] and greater emotional and behavioural problems [7] in the children with an MSaffected parent. Both studies were of medium quality. Studies measuring the caregiving activities of children with an MS parent highlighted that these children had more responsibility and obligations compared with those children with healthy parents and consequently a greater sense of burden, anger and lower levels of life satisfaction $[19,25]$. One study was scored low quality, the other medium. Furthermore, adolescents with an MS parent exhibited a higher degree of responsibility and experienced more fear and anxiety compared with adolescents with healthy parents [24]. Higher conflict, lower cohesion and a general 'lack of togetherness' was reported by children with an MS parent compare with children of non-MS parents in one study [22] and higher levels of body concern, hostility constraint, interpersonal relations and a pattern of false maturity in another [12]. Both were of medium quality.

Several studies compared the children of MS parent's psychosocial score to the general population norm $[8,15]$. One study estimated that 25\% (45 of 174) of children with MS parents were classified as being "at risk" for a mental health problem compared with 12 to $20 \%$ of children in the general population [15]. Furthermore, adolescent's self-reported scoring for internalizing disorders was significantly over the expected normal [8]. Both were rated as low quality studies due to the failure to adjust for important demographic variables, such as SES and having suboptimal data collection.

\section{Quantitative studies with no comparison group}

Of the remaining three quantitative studies with no comparison group, one demonstrated that children of parents with MS were at risk of mental health problems and would benefit from individual psychotherapy [23]. One study suggested that children who had partial information about their parent's condition exhibited significantly more problems as compared with children who had explicit information or no information [21]. In addition one longitudinal study found that youths with greater caregiving responsibilities reported lower life satisfaction, higher somatization and higher emotional and behavioural difficulties [20]. All three studies were of low methodological quality, with interpretation of findings sometimes difficult in the light of no comparator group.

\section{Qualitative studies}

Three of the four qualitative studies included described both positive and negative experiences related to having a parent with MS [10,14,17]. Higher family tension and extra responsibilities which limited children's involvement with peers and time spent at play and learning were associated with having a parent with MS [10]. Further, all children expressed anxiety about both the immediate and long-term health and well-being of their parents [10,14]. Both studies were high quality. Last, a medium quality study noted that children's limited knowledge and understanding of the disorder and the related implications of having a parent with MS seemed to be a threat to their achievement of happiness [17].

\section{Neutral (or no measurable) psychosocial effects}

In contrast to some of the findings above, no statistically significant differences on body image distortion were found in children with an MS parent vs. a "healthy parent" [18]. Furthermore, no significant differences on motherdaughter interactions during work and play tasks were observed when the mother had MS vs. "healthy" mothers and daughters [16]. One study was of low quality [16], the other medium [18]. In addition, two studies showed that these children did not appear to differ from the community norms for overall difficulties and externalizing problems $[5,8]$. Yet these children were over three times more likely than a community sample to be perceived by their affected parents as having psychological problems. This might not be due to the child's actual psychological well being, rather could relate to the parents' perception of their own MS $[5,8]$. Both studies were of low quality. Last, a qualitative study (of medium quality) noted that for the most part, children with an MS parent reported a good quality of life [17].

\section{Positive psychosocial aspects}

In one quantitative study, findings indicated that although parental MS was associated with a higher social-emotional burden, and a greater share of domestic-household duties, this actually lead to an increased in pro-social behaviour in youth [20]. Furthermore, these youth voiced a source of pride when taking on family responsibilities [10,17]. Children described having higher personal competence and feeling more empathetic to others and more "grown-up", as the benefits to having a parent with MS [13,14].

\section{Discussion}

In this systematic review we evaluated the association between parental MS and adjustment in children and adolescents. Overall, while most studies tended to report that children of MS patients exhibited negative psychosocial behaviour compared with children of "healthy" parents, some positive aspects in caring for a parents with MS 
were also highlighted. However, overall the strength of the evidence was rather weak, with only 2 of 18 studies rated as 'high quality', which makes it difficult to draw evidencebased conclusions $[10,14]$.

Nonetheless, our findings are broadly consistent with other systematic reviews, which also report negative psychosocial effects in children living with a parent with a physical disability or a chronic illness [3,38,39]. A metaanalysis looking at children who have a parent with a chronic illness found that overall these children displayed significantly more internalizing related behaviour (i.e. anxiety, depression, withdrawal) than children with healthy parents [3]. Furthermore, in a population-based sample of children with a parent dealing with a serious physical illness, there was an elevated risk of psychosocial maladjustment, with internalizing problems being more prevalent than externalizing problems, such as aggression and delinquent behaviour [1].

Within our systematic review we found suggestion that children had higher rates of body concern, depression, anxiety, somatization, difficulty in relating to others and greater emotional and behavioural problems [5,7,12,15,19,20,23,25]. Children also perceived their families as being less cohesive with greater tension and isolation, as compared with the general population [14,22]. Furthermore, uncertainty regarding the future, as well as illness exacerbation, posed a degree of fear and anxiety in children [25,40]. Caregiving roles and the stigma attached to a parent's MS were also sources of stress for children [20]. Specifically for adolescents, greater family responsibilities were linked to fewer social relationships and higher distress $[19,20,24]$. However, several studies found no measurable effect (negative or positive) of having a parent with MS [5,8,16,18], and a few found some positive effects, such as higher personal competence $[13,14]$.

This pattern of positive and negative outcomes could reflect the costs and benefits associated with caregiving that is also evident in adult caregivers [41]. Some children in our review described pride in their caregiving abilities, as these children completed tasks above those of their peers [10]. However, there are circumstances, when children may feel they have no choice but to become caregivers, and that can intensify the overall family stress $[19,38]$. Children are more prone to becoming caregivers in single-parent families, low-income families, families who do not have access to home care support, and families with little social support $[5,42]$.

Our systematic review highlighted that one of the factors associated with poor adjustment in children was their limited knowledge and understanding of MS [17,21]. This concurs with other studies which indicate that it is important to provide children information about MS, tailored to their developmental level, as this lack of information has caused some children to believe that their own or other people's behaviour affected their parents' illness [43,44]. Young children, in particular, appear to have a need for information that is currently not being met [43]. Children may need better information on the etiology of MS and be reassured that the risk for them to contract MS is minimal [43]. Children who are unaware of their parent's illness may display high levels of anxiety and distress as they witness family tension without being aware of its source [21]. Interestingly, educated mothers are less likely to provide information regarding their illness to their children [21]. This observation is worthy of further investigation, especially as several studies show that MS patients who participate in research have a higher socioeconomic status compared with other chronic illness patients, which could potentially lead to selection and reporting bias $[5,45]$.

In our systematic review, studies reported that family dysfunction and lack of social support were associated with a child's externalizing problems, while the severity of impairment of the ill mother predicted children's internalizing problems $[7,14]$. This is consistent with other studies which showed that lower level of depression in the affected parent has been related to positive coping ability of the children [46]. Likewise, the coping ability of the healthy parents appeared to be a strong predictor of whether children successfully cope with the disease $[46,47]$. Nonetheless, no study in our systematic review looked at fatigue as a risk factor, whilst fatigue has been shown to be one of the most common, yet "hidden", symptoms of MS [48]. Parents with MS identified fatigue as one of the primary problem that interferes with important parenting functioning, ranging from difficulties in being involved with day-to-day activities, to lack of patience [20]. Furthermore, in a group of patients with different chronic illnesses, including MS, one study demonstrated that maternal fatigue potentially mediates some of the relationship between maternal depression and maladaptive child outcomes [45]. Other factors which emerged as potentially influencing a child's adjustment to parental illness from the included studies were: gender of the parent and the child [20,46,47], children's age and developmental stage $[10,19]$, level of social support [10], physical condition or disability caused by the disease [19], single parenthood and family environment $[10,15,19,23]$.

Interpretation of our systematic review is constrained by limitations in the original studies, particularly exposure assessment and potential sources of bias. First, none of the studies included in the present systematic review used objective measures of child psychosocial adjustment. Second, studies failed to account for important confounding or to provide baseline characteristics of the participants that limit the generalizability of the findings. Third, many studies did not include a comparison group, which is a critical piece in shedding light on whether the patterns of 
findings in the studies are specific to children who have a parent with an illness. Last, relying on cross-sectional design fails to disentangle the interactions between normal child developmental variations and the variations produced by the progressive nature of MS, such as difficulties in the transition to adulthood. This is particularly relevant given that disability in MS can often be minimal in the early stages of the disease, and the overall lifespan may not be affected as with other chronic diseases. Furthermore, to explore if there is an MS specific characteristics that influence children's development, it would be of interest to investigate the psychosocial wellbeing of children with MS parents as compared to other chronic diseases.

To overcome many of the deficiencies raised above, we recommend a population-based approach with inclusion of a representative comparison group to avoid selection biases that may have limited many studies. In addition, rigorous, objective, and well-validated measurement tools are needed, of which several are available, namely, the Early Child Development Instrument [49], or the Child Behaviour Checklist [27]. Along with this, measurement of appropriate confounders or explanatory variables, such as socioeconomic status, gender of the child or the marital status of the parents should be considered. Ideally these would be combined with clinical characteristics of the affected parents, such as disease duration, level of disability or presence of comorbidity, to populate a large studyspecific dataset of patients and their children. Findings of these studies would help to inform policy making for healthier communities and assist us in developing and evaluating family centered interventions to improve child and family outcomes [50].

\section{Potential limitations of the review process}

Some of the following potential limitations are common across systematic reviews, such as publication bias and study selection process. We sought to mitigate these by having two independent reviewers, and by checking reference lists of previously published reviews and articles retrieved in the search for studies that we might have missed. Despite these measures, the selection and qualitative synthesis of eligible studies can still be a rather subjective process. However, by using a standardized form to extract the data, and assessing methodological quality using a validated checklist, we strived to maximize the objectivity in our search strategy. For observational and epidemiological study designs, there is currently a lack of consensus regarding the most appropriate methodology for assessing quality in the context of a systematic review [51]. Although the GATE tool is an excellent tool to critically appraise different types of studies, it does not assign a grade or score to studies and therefore its use and validity might be limited [52,53].

\section{Conclusion}

Exploring the relationship between parental MS and a child's psychosocial adjustment is challenging. Due to the relatively few studies of high methodological quality, it is difficult to draw strong evidenced-based conclusions from the present literature and thus more extensive and higher quality research in this area is greatly needed. From the limited available evidence, it appears that exposure to parental MS may put children at a higher risk of psychosocial problems compared with children with parents not living with a chronic disease. Although the few studies examining the impact of parental chronic disease on children's development and health represent important first steps, many have serious methodological limitations, particularly with respect to ascertaining individuals with definite MS, and potential sources of bias, such as failure to adjust for important demographic variables, i.e. socio-economic status, lack of a suitable comparison group and sub-optimal data collection. To gain further insight and to assess this relationship accurately we need more population-based studies using objective measures of developmental health, using reliable and valid measurement instruments. Further research is needed before appropriate evidenced-based recommendations can be made, however, it appears pragmatic to advise healthcare professionals, and community partners, such as educators, patient group and policy makers, to be cognizant of the broad impact of chronic parental illness on the developing child.

\section{Additional files}

Additional file 1: Search strategies and results.

Additional file 2: Data extract form.

\section{Abbreviation}

MS: Multiple Sclerosis; GATE: Graphic Appraisal Tool for Epidemiology: EDSS: Kurtzke's Expanded Disability Status Scale.

\section{Competing interests}

The authors' declare that they have no competing interests.

\section{Authors' contributions}

NR was responsible for the design and conceptualization of the study, analysis and interpretation of the data, drafting and revising the manuscript. RN participated in analysis and interpretation of the data. RAM assisted in interpretation of the data and revising the manuscript. WTM assisted with interpretation of the data and revising the manuscript. HT participated in analysis and interpretation of the data and helped to draft the manuscript. All authors read and approved the final manuscript.

\section{Author details}

${ }^{1}$ School of Population and Public Health, Faculty of Medicine, University of British Columbia, 2206 East Mall, Vancouver, British Columbia, V6T 1Z3,

Canada. ${ }^{2}$ Departments of Internal Medicine and Community Health Sciences, University of Manitoba, Health Sciences Centre, GF 543-820 Sherbrook Street, Winnipeg, Manitoba, R3A 1R9, Canada. ${ }^{3}$ Division of Developmental-Behavioral Pediatrics, Department of Pediatrics, University of California, 3333 California Street, Suite 245, San Francisco, CA 94118, USA. ${ }^{4}$ Brain Research Centre and Department of Medicine (Division of Neurology), Faculty of Medicine, University of British Columbia, Vancouver, Canada. ${ }^{5}$ Vancouver Coastal 
Health Research Institute, S178 Koerner Pavilion, 2211 Wesbrook Mall, Vancouver, British Columbia, V6T 2B5, Canada.

Received: 7 March 2014 Accepted: 2 May 2014

Published: 19 May 2014

\section{References}

1. Barkmann C, Romer G, Watson M, Schulte-Markwort M: Parental physical illness as a risk for psychosocial maladjustment in children and adolescents: epidemiological findings from a national survey in Germany. Psychosomatics 2007, 48(6):476-481.

2. Sieh DS, Visser-Meily JM, Meijer AM: Differential outcomes of adolescents with chronically ill and healthy parents. J Child Fam Stud 2013, 22(2):209-218

3. Sieh DS, Meijer AM, Oort FJ, Visser-Meily JM, Van der Leij DA: Problem behavior in children of chronically ill parents: a meta-analysis. Clin Child Fam Psychol Rev 2010, 13(4):384-397.

4. Leary SM, Porter B, Thompson AJ: Multiple sclerosis: diagnosis and the management of acute relapses. Postgrad Med J 2005, 81(955):302-308.

5. De Judicibus MA, McCabe MP: The impact of parental multiple sclerosis on the adjustment of children and adolescents. Adolescence 2004, 39(155):551-569.

6. Smeltzer SC: Reproductive decision making in women with multiple sclerosis. J Neurosci Nurs 2002, 34(3):145-157.

7. Diareme S, Tsiantis J, Kolaitis G, Ferentinos S, Tsalamanios E, Paliokosta E, Anasontzi S, Lympinaki E, Anagnostopoulos DC, Voumvourakis C, Romer G: Emotional and behavioural difficulties in children of parents with multiple sclerosis: a controlled study in Greece. Eur Child Adolesc Psychiatry 2006, 15(6):309-318.

8. Steck B, Amsler F, Grether A, Dillier AS, Baldus C, Haagen M, Diareme L, Tsiantis J, Kappos L, Burgin D, Romer G: Mental health problems in children of somatically ill parents, e.g. multiple sclerosis. Eur Child Adolesc Psychiatry 2007, 16(3):199-207.

9. Growing Up Strong: Supporting the Children of Parents with MS. Canada: Multiple Sclerosis Society of Canada; 2008 [mssociety.ca/en/pdf/ GrowingUpStrongLiteratureReview.pdf]

10. Turpin M, Leech C, Hackenberg L: Living with parental multiple sclerosis: children's experiences and clinical implications. Can J Occup Ther 2008 75(3):149-156.

11. Jackson R, Ameratunga S, Broad J, Connor J, Lethaby A, Robb G, Wells S, Glasziou P, Heneghan C: The GATE frame: critical appraisal with pictures. Evidence Based Medi 2006, 11(2):35-38.

12. Arnaud $\mathrm{SH}$ : Some psychological characteristics of children of multiple sclerotics. Psychosom Med 1959, 21:8-22.

13. Blackford KA: A child's growing up with a parent who has multiple sclerosis: theories and experiences. Disabil \& Soc 1999, 14(5):673-685.

14. Bogosian A, Moss-Morris R, Bishop FL, Hadwin J: How do adolescents adjust to their parent's multiple sclerosis? An interview study. $\mathrm{Br} J$ Health Psychol 2011, 16(Pt 2):430-444.

15. Brandt $P$, Weinert $C$ : Children's mental health in families experiencing multiple sclerosis. J Fam Nurs 1998, 4(1):41-64.

16. Crist P: Contingent Interaction During Work and Play Tasks for Mothers with Multiple Sclerosis and Their Daughters. Am J Occup Ther 1993, 47(2):121-131.

17. Kikuchi JF: The reported quality of life of children and adolescents of parents with multiple sclerosis. Recent Adv Nurs 1987, 16:163-191.

18. Olgas M: The relationship between parents' health status and body image of their children. Nurs Res 1974, 23(4):319-324.

19. Pakenham Kl, Bursnall S: Relations between social support, appraisal and coping and both positive and negative outcomes for children of a parent with multiple sclerosis and comparisons with children of healthy parents. Clin Rehabil 2006, 20(8):709-723.

20. Pakenham Kl, Cox S: The nature of caregiving in children of a parent with multiple sclerosis from multiple sources and the associations between caregiving activities and youth adjustment overtime. Psychol Health 2012, 27(3):324-346.

21. Paliokosta E, Diareme S, Kolaitis G, Tsalamanios E, Ferentinos S, Anasontzi S, Lympinaki E, Tsiantis A, Tsiantis J, Karageorgiou C, Romer G: Breaking Bad News: Communication Around Parental Multiple Sclerosis With Children. Families, Systems and Health 2009, 27(1):64-76.
22. Peters LC, Esses LM: Family environment as perceived by children with a chronically ill parent. J Chronic Dis 1985, 38(4):301-308.

23. Steck B, Amsler F, Dillier AS, Grether A, Kappos L, Bürgin D: Indication for Psychotherapy in Offspring of a Parent Affected by a Chronic Somatic Disease (e.g. Multiple Sclerosis). Psychopathology 2005, 38(1):38-48.

24. Yahav R, Vosburgh J, Miller A: Emotional responses of children and adolescents to parents with multiple sclerosis. Mult Scler 2005, 11(4):464-468.

25. Yahav R, Vosburgh J, Miller A: Separation-individuation processes of adolescent children of parents with multiple sclerosis. Mult Scler 2007, 13(1):87-94.

26. Klopfer B, Ainsworth MD, Klopfer WG, Holt RR: Developments in the Rorschach Technique, Vol. I. Yonkerson-Hudson, N. Y: World Book Company; 1954.

27. Achenbach TM: Child behavior checklist/4-18. Burlington: University of Vermont; 1991

28. Goodman R: The Strengths and Difficulties Questionnaire: a research note. J Child Psychol Psychiatry 1997, 38(5):581-586.

29. Achenbach TM: Integrative guide for the 1991 CBCL/4-18, YSR, and TRF profiles. Burlington, $\mathrm{VT}$ : Department of Psychiatry University of Vermont Burlington; 1991

30. Achenbach TM, Edelbrock C: Manual for the youth self-report and profile. Burlington, VT: University of Vermont Department of Psychiatry; 1989.

31. Levine JB, Green CJ, Millon T: The separation-individuation test of adolescence. J Pers Assess 1986, 50(1):123-139.

32. Koppitz EM: Psychological evaluation of children's human figure drawings. New York: Grune \& Stratton; 1968

33. Osgood CE, Suci GJ, Tannenbaum P: The measurement of meaning, vol. 47. Urbana: University of Illinois Press; 1957.

34. Secord PF, Jourard SM: The appraisal of body-cathexis: body-cathexis and the self. J Consult Psychol 1953, 17(5):343.

35. Ireland MJ, Pakenham KI: The nature of youth care tasks in families experiencing chronic illness/disability: Development of the Youth Activities of Caregiving Scale (YACS). Psychol Health 2010, 25(6):713-731.

36. Moos RH, Moos BS: Family Environment Scale Manual: Development, Applications, Research - Third Edition. Palo Alto, CA: Consulting Psychologists Press; 1994.

37. Kurtzke JF: Rating neurologic impairment in multiple sclerosis: an expanded disability status scale (EDSS). Neurology 1983, 33(11):1444-1452.

38. Bogosian A, Moss-Morris R, Hadwin J: Psychosocial adjustment in children and adolescents with a parent with multiple sclerosis: a systematic review. Clin Rehabil 2010, 24(9):789-801.

39. Kelley SDM, Sikka A, Venkatesan S: A review of research on parental disability: Implications for research and counseling practice. Rehabil Couns Bull 1997, 41(2):105-121.

40. Deatrick JA, Brennan D, Cameron ME: Mothers with multiple sclerosis and their children: effects of fatigue and exacerbations on maternal support. Nurs Res 1998, 47(4):205-210.

41. Pakenham Kl: The positive impact of multiple sclerosis (MS) on carers: associations between carer benefit finding and positive and negative adjustment domains. Disabil Rehabil 2005, 27(17):985-997.

42. Warren S, Turpin K, Pohar S, Jones C, Warren K: Comorbidity and healthrelated quality of life in people with multiple sclerosis. Int J Mult Scler Care 2009, 11:6-16

43. Cross T, Rintell D: Children's perceptions of parental multiple sclerosis. Psychol, Health Med 1999, 4(4):355-360.

44. Coles AR, Pakenham Kl, Leech C: Evaluation of an intensive psychosocial intervention for children of parents with multiple sclerosis. Rehabil Psychol 2007, 52(2):133-142.

45. White $\mathrm{CP}$, King $\mathrm{K}$ : Is Maternal Fatigue Mediating the Relationship between Maternal Depression and Child Outcomes? J Child Fam Stud 2011, 20(6):844-853.

46. Ehrensperger MM, Grether A, Romer G, Berres M, Monsch AU, Kappos L, Steck B: Neuropsychological dysfunction, depression, physical disability, and coping processes in families with a parent affected by multiple sclerosis. Mult Scler 2008, 14(8):1106-1112.

47. Steck B, Amsler F, Kappos L, Burgin D: Gender-specific differences in the process of coping in families with a parent affected by a chronic somatic disease (e.g. multiple sclerosis). Psychopathology 2001, 34(5):236-244.

48. Hadjimichael $\mathrm{O}$, Vollmer T, Oleen-Burkey M: Fatigue characteristics in multiple sclerosis: the North American Research Committee on Multiple Sclerosis (NARCOMS) survey. Health Qual Life Outcomes 2008, 6(1):100.

49. Janus M, Offord DR: Development and psychometric properties of the early development instrument (EDI): A measure of children's school readiness. Can J Behav Sci 2007, 39(1):1-22. 
50. Razaz N, Hertzman C, Marrie RA, Tremlett H, Boyce WT: Children of chronically ill parents: The Silence of Research. Child Care Health Dev. Accepted (CCH12120).

51. Sanderson S, Tatt ID, Higgins JP: Tools for assessing quality and susceptibility to bias in observational studies in epidemiology: a systematic review and annotated bibliography. Int J Epidemiol 2007, 36(3):666-676.

52. Baker A, Young K, Potter J, Madan I: A review of grading systems for evidence-based guidelines produced by medical specialties. Clin Med 2010, 10(4):358-363.

53. Robb G, Arroll B, Reid D, Goodyear-Smith F: Summary of an evidencebased guideline on soft tissue shoulder injuries and related disordersPart 1: assessment. J Prim Health Care 2010, 1(1):36-41.

doi:10.1186/1471-2377-14-107

Cite this article as: Razaz et al:: Children and adolescents adjustment to parental multiple sclerosis: a systematic review. BMC Neurology 2014 14:107.

\section{Submit your next manuscript to BioMed Central and take full advantage of:}

- Convenient online submission

- Thorough peer review

- No space constraints or color figure charges

- Immediate publication on acceptance

- Inclusion in PubMed, CAS, Scopus and Google Scholar

- Research which is freely available for redistribution 